(i) Original Article

(ii) Tobias Hoeppner $\mathrm{MD}^{1}$

Meredith Borland $\mathrm{MBBS}^{1,2}$

Franz E Babl MD ${ }^{3,4,5}$

Jocelyn Neutze $\mathrm{MBChB}^{6}$

Natalie Phillips $\mathrm{MBBS}^{7,8,9}$

David Krieser MBBS ${ }^{4,5,10}$

Stuart R Dalziel MBChB PhD 11,12

Andrew Davidson MBBS ${ }^{4,5,13}$

Susan Donath $\mathrm{PhD}^{4,5}$

Kim Jachno BSc ${ }^{4}$

$=$ Mike South MD ${ }^{4,5,14}$

Amanda Williams $\mathrm{RN}^{4,5}$

Guicheng Zhang $\mathrm{PhD}^{15,16}$

Ed Oakley MBBS $\mathrm{MB}^{3,4,5}$

For the Paediatric Research in Emergency Departments International Collaborative (PREDICT)

(iv)

${ }^{1}$ Department of Emergency Medicine, Princess Margaret Hospital, Perth, WA, Australia

${ }^{2}$ School of Paediatrics and Child Health and School of Primary, Rural and Aboriginal Health, University of Western Australia, Perth, WA, Australia

${ }^{3}$ Department of Emergency Medicine, Royal Children's Hospital, Melbourne, VIC, Australia

${ }^{4}$ Murdoch Children's Research Institute, Melbourne, VIC, Australia

${ }^{5}$ Department of Paediatrics, Faculty of Medicine, Dentistry and Health Sciences, University of Melbourne, VIC, Australia.

${ }^{6}$ Department of Emergency Medicine, Kidz First Children's Hospital, Counties Manukau Health, Auckland, New Zealand

${ }^{7}$ Emergency Department, Lady Cilento Children's Hospital, Brisbane, QLD, Australia

${ }^{8}$ Children's Health Research Centre, University of Queensland Medical Research Institute, Brisbane, QLD, Australia

${ }^{9}$ Faculty of Medicine, University of Queensland, Brisbane, QLD, Australia

${ }^{10}$ Department of Emergency Medicine, Sunshine Hospital, Melbourne, VIC, Australia

${ }^{11}$ Children's Emergency Department, Starship Children's Hospital, Auckland, New Zealand

${ }^{12}$ Liggins Institute, University of Auckland, Auckland, New Zealand

${ }^{13}$ Department of Anaesthesia, Royal Children's Hospital Melbourne, VIC, Australia

${ }^{14}$ Department of Medicine, Royal Children's Hospital Melbourne, VIC, Australia

${ }^{15}$ School of Public Health, Curtin University, Perth, WA, Australia

${ }^{16}$ Centre for Genetic Origins of Health and Disease, Curtin University and the University of Western Australia, Perth, WA, Australia

This is the author manuscript accepted for publication and has undergone full peer review but has not been through the copyediting, typesetting, pagination and proofreading process, which may lead to differences between this version and the Version of Record. Please cite this article as doi: $10.1111 /$ jpc.13614

This article is protected by copyright. All rights reserved. 
(v) Dr Tobias Hoeppner, Department of Emergency Medicine, Princess Margaret Hospital for Children, Roberts Road, Subiaco, Western Australia 6008, Australia, telephone 089340 8222, email tobias.hoeppner@health.wa.gov.au, fax 0893408362

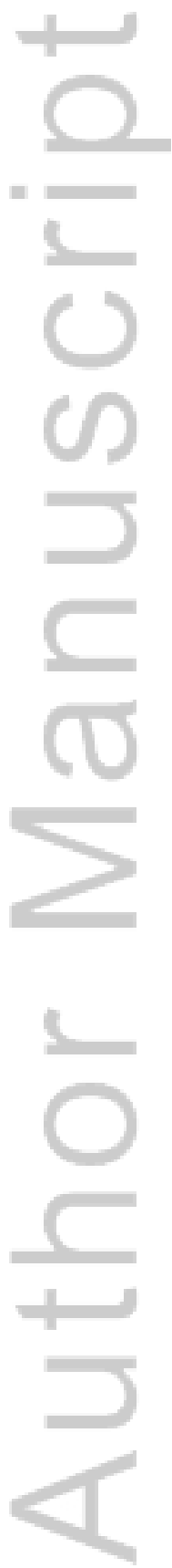

This article is protected by copyright. All rights reserved. 


\title{
Influence of weather on incidence of bronchiolitis in Australia and New Zealand
}

\begin{abstract}
Aim: We aimed to examine the impact of weather on hospital admissions with bronchiolitis in Australia and New Zealand.

Methods: We collected data for inpatient admissions of infants aged 2 to 12 months to seven hospitals in four cities in Australia and New Zealand from 2009 until 2011. Correlation of hospital admissions with minimum daily temperature, wind speed, relative humidity and rainfall was examined using linear, Poisson and negative binomial regression analyses as well as general estimated equation models. To account for possible lag between exposure to weather and admission to hospital, analyses were conducted for time lags of zero to four weeks.
\end{abstract}

Results: During the study period, 3876 patients were admitted to the study hospitals. Hospital admissions showed strong seasonality with peaks in wintertime, onset in autumn and offset in spring. The onset of peak incidence was preceded by a drop in temperature. Minimum temperature was inversely correlated with hospital admissions, whereas wind speed was directly correlated. These correlations were sustained for time lags of up to four weeks. Standardised correlation coefficients ranged from -0.14 to -0.54 for minimum temperature and 0.18 to 0.39 for wind speed. Relative humidity and rainfall showed no correlation with hospital admissions in our study.

Conclusion: A decrease in temperature and increasing wind speed are associated with increasing incidence of bronchiolitis hospital admissions in Australia and New Zealand.

\section{Key Words}

Bronchiolitis, Incidence, Weather, Australia, New Zealand

\section{Learning Points}

What is already known on this topic: 1 . Worldwide, bronchiolitis presents in seasonal epidemics. 2 . There is conflicting evidence regarding the influence of weather on the incidence of bronchiolitis.

What this paper adds: 1. In Australia and New Zealand, the bronchiolitis season mirrors the pattern seen in the Northern Hemisphere with onset in autumn, peak in summer and offset in autumn. 2. Temperature and wind speed correlate with the incidence of bronchiolitis hospital admissions.

This article is protected by copyright. All rights reserved. 


\section{Introduction}

Bronchiolitis is the leading cause of hospital admissions in children younger than one year in Europe ${ }^{1-3}$, North America ${ }^{4}$, Australia, ${ }^{5,6}$ and New Zealand ${ }^{7,8}$. While incidence of hospital admission ranges from 6 to 72 per 1000 live births per year in industrialised countries, it is closer to 200 per 1000 in remote indigenous populations in North America ${ }^{9}$ and Australia ${ }^{6}$.

The most important infectious agent causing bronchiolitis is human respiratory syncytial virus (RSV) which can be isolated from $50-90 \%$ of children admitted to hospital with bronchiolitis ${ }^{10}$. An Australian study has demonstrated similar seasonal profiles of RSV notifications and hospital admissions with bronchiolitis ${ }^{11}$.

A host of studies in diverse climatic environments have examined the seasonality of bronchiolitis. Most epidemiological studies report a peak incidence of RSV-induced bronchiolitis during winter months or "wet season" in temperate climates but there is marked regional and year-to-year variability in the time of onset and duration of the season ${ }^{12-15}$. In equatorial regions, RSV-related disease can be prevalent year-round.

A review from 2002 summarised findings of some 60 studies examining seasonality in RSV infection ${ }^{16}$. This included only two older Australasian studies. The first one of those monitored RSV isolates in a paediatric hospital over five years ${ }^{17}$. For three years, RSV prevalence showed a seasonal pattern with onset in autumn, end in spring and mid-winter peaks. During two years, RSV was first detected in mid-summer, peaked in autumn and was present throughout most months of the year. The second paper demonstrated that the majority of RSV isolates from three Australian cities were obtained from April to September with a peak in July. However, no epidemiological data could be derived from this study as the investigation was focused on virological aspects ${ }^{18}$.

A further study from subtropical Australia demonstrated seasonality of bronchiolitis peaking in March only for non-Aboriginal children, whereas Aboriginal and Torres-Strait Islander children were affected yearround $^{19}$. For New Zealand, viral surveillance also found the vast majority of isolates of RSV in winter with year-to-year variation in onset, offset and peak of incidence ${ }^{20}$. In central arid Australia, seasonality was less marked with hospital admissions throughout the year but more common in winter months ${ }^{21}$. The biggest Australasian study examining seasonality of hospital admissions with bronchiolitis in three large regions found decreasing seasonal variation with closer proximity to tropical zones ${ }^{22}$.

Studies investigating the influence of weather parameters on onset and end of the RSV season are difficult to compare due to varying methodologies and definitions of RSV-related illness. They suggest that relative humidity and temperature are the most consistent parameters associated with peak incidence of RSVrelated illness. 
We present the first study to examine the relationship between weather and incidence of bronchiolitis presentations to hospital in Australia and New Zealand.

\section{Methods}

\section{Study subjects}

Data for this study were derived from two samples. A previous prospective multicentre study (CRIB) enrolled infants aged eight weeks to twelve months who were hospitalised in one of seven participating paediatric centres in Australia and New Zealand with bronchiolitis during 2009-11 ${ }^{23}$. The primary aim of the CRIB study was to compare the efficacy and safety of nasogastric vs intravenous hydration. Due to logistical and economic reasons, recruitment was started and stopped at different times across study sites. Bronchiolitis presentations were monitored by site investigators; recruitment was commenced when there was a perceived increase in presentations and ceased when presentations waned. Recruitment for all study sites was terminated when the pre-determined number of subjects had been randomised.

In this current study, we also included all patients who were prospectively identified for the CRIB study but who were missed or excluded. All patients aged 2-12 months (corrected for prematurity) admitted to one of the study hospitals from 2009 to 2011 with bronchiolitis were eligible. For the purposes of the study bronchiolitis was defined according to the American Academy of Pediatrics guidelines ${ }^{24}$ as symptoms and signs of respiratory distress (tachypnoea, recessions, nasal flaring, or cyanosis) associated with symptoms of a viral respiratory tract infection.

Study sites were in different geographical regions (see Figure 1) and included Brisbane (Queensland), Perth (Western Australia), and Melbourne (Victoria) in Australia and Auckland in New Zealand.

\section{Data collection}

Demographic and medical patient data were entered on a standardised data collection form at the individual hospitals. Collated forms were sent to a central site (RCH Melbourne) and entered into an Epidata database (Epidata, Odense, Denmark).

\section{Weather data}

Weather data for 2009-2011 were obtained from the Australian Bureau of Meteorology and the Meteorological Service of New Zealand, respectively. For each participating site, the measuring station 
closest to the participating hospital was selected. Mean daily relative humidity, wind speed and cumulative rainfall were calculated. Temperature was represented by minimal daily values, which were converted into weekly mean values. Weather data were entered into an Excel spreadsheet (Excel 2003, Microsoft, Redmond, USA).

\section{Statistical analysis}

Regression analysis was firstly performed using linear regression. As the number of admissions was a count variable, Poisson and negative binominal regression were further employed to verify the results. Considering the cluster effects of each hospital, general estimated equation models were also used in the analysis. Stata (Version 9, Statacorp, College Station, Texas, USA) and SPSS (Version 19, IBM Corp., Armonk, NY, USA) were utilised. In the regression analysis, different hospitals were included as a categorical confounding variable for the adjustment. P-values less than 0.05 were considered significant.

To assess for the possibility of a delay between exposure to weather events and the development of bronchiolitis, correlation was computed with time lags of $0,1,2,3$ and 4 weeks.

\section{Ethics}

Ethics approval was sought and obtained through the research ethics committee at each site. As this was a retrospective observational study, consent for participation was waived.

\section{Results}

\section{Study subjects}

During the study period, 3876 patients were admitted to the study hospitals. Median age was 6.3 months (IQR 4.1-8.7). 2387 (61.5\%) patients were male. Median length of stay in hospital was 2.28 days. Nasopharyngeal aspirates were obtained from 2335 study subjects. Of these, 1089 (46.6\%) tested positive for RSV.

\section{Weather data}

Data were collected from six weather stations over the 159 week study period. For one of the two Melbourne stations, wind speed and barometric pressure data were unavailable for 124 weeks. This resulted in a total of 31000 data points available for analysis. 


\section{Seasonality}

In all seven hospitals, hospital admissions with bronchiolitis showed strong seasonality with peaks in wintertime (Figure 2). Onset of bronchiolitis season ranged from early April to mid-June, offset ranged from mid-September to late-October. Variation from year to year was minimal for each individual site.

\section{Weather and incidence of hospital admissions}

The temperature/admission charts (Figure 2) suggest that the onset of peak incidence of hospital admissions was preceded by a drop in temperature. The peaks appear less marked in the subtropical climate of Brisbane.

In the linear regression analysis, neither rainfall nor barometric pressure reached statistical significance. Correlation coefficients for relative humidity were less than 0.2 at all lag times. Minimum temperature and wind speed correlated significantly with hospital admissions with a time lag of up to four weeks (Table 1).

Minimum temperature was negatively correlated with the number of hospital admissions (i.e. the lower the temperature, the more admissions) across all time lags, with largest effects at two weeks offset and smaller relative effects at three and four weeks offset. Wind speed correlated with admissions over all time lags.

In the generalised estimated equation model, minimum temperature correlated significantly only to a time lag of 2 weeks. Wind speed reached significance at zero, one and three weeks of lag.

The negative binomial regression model confirmed minimum temperature's inverse correlation with the number of admissions over all lag times; and the positive correlation with wind speed over all time lags.

Considering all three models in conjunction, minimum temperature and wind speed appeared to be the most convincing variables to explain variation in hospital admissions.

\section{Discussion}

This study is the first to directly examine the relationship between weather and the incidence of bronchiolitis hospital admissions in Australasia. As demonstrated in other geographical areas, our study shows a seasonal pattern typical for temperate climates with peaks of incidence in winter. Only minimum temperature and wind speed correlated with the incidence of bronchiolitis. For all contributing centres, the onset of the annual epidemic was preceded by a drop in temperature but there appeared to be no identifiable threshold predicting the onset of bronchiolitis season. 
Although comparison is hampered by different methodologies, our data confirm previous findings that temperature correlates inversely with incidence of bronchiolitis ${ }^{25-37}$.

Conversely, Chan et al. reported a positive correlation between temperature and hospital admissions with RSV-positive bronchiolitis in Hong Kong ${ }^{38}$. Two further studies examining temperature as a contributor to the incidence of bronchiolitis found no correlation ${ }^{34,39}$.

In addition to temperature, we found a positive correlation of wind speed and incidence of bronchiolitis. This was in keeping with three previous studies ${ }^{33,35,36}$. A further four studies found no correlation ${ }^{28,31,34,39}$. In our study, there was no correlation between relative humidity and the incidence of bronchiolitis. Five

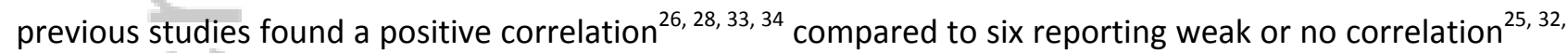
$35,38,39$

In conclusion, lower temperature seems to be the most consistent factor implicated in the annual epidemics of bronchiolitis in temperate climates. The question of what exactly lies behind this correlation allows for a number of theories.

Firstly, lower temperatures could cause people to gather inside more and hence facilitate person-to-person transmission of the viruses causing bronchiolitis. However, increased rainfall could be expected to have a similar effect and this could not be demonstrated in our population.

Secondly, lower temperatures could directly affect the survivability of viruses outside of infected hosts. RSV can be transmitted via fomites and in vitro viability of RSV correlates inversely with ambient temperature ${ }^{40,}$ ${ }^{41}$.

Thirdly, temperature could represent a proxy for other environmental factors that affect virulence of RSV. One in-vitro study showed that virus replication in infected human monocyte-derived dendritic cells followed the seasonal pattern of RSV epidemics and that replication can be stimulated by exogenous nitric oxide (NO), suggesting that environmental factors may trigger annual outbreaks ${ }^{42}$. Studies attempting to correlate air quality parameters with the incidence of bronchiolitis have produced conflicting results, but none used $\mathrm{NO}$ as a marker for air quality $33,43,44$.

Lastly, temperature could directly affect host immunity and thereby increase susceptibility to infection. RSV carriage has been shown in asymptomatic adults with chronic obstructive pulmonary disease ${ }^{45}$ and children without respiratory symptoms ${ }^{46}$, thus suggesting that there is a human reservoir. Despite minimal antigenic shift, re-infection is common and allows the virus to remain in circulation ${ }^{47}$. Foxman et al. demonstrated that temperature affects immune response to rhinovirus in mouse airway cells ${ }^{48}$. In a similar manner and with RSV in perennial circulation, a drop in temperature could increase susceptibility for symptomatic 
infection in a large number of individuals and thereby trigger the annual epidemic observed in our and other studies.

Our study provides robust data to inform future studies exploring the link between temperature and the incidence of RSV bronchiolitis.

\section{Clinical relevance}

There is some evidence that day-to-day Emergency Department workload is predictable based on calendar variables $^{49,50}$. During winter months, bronchiolitis is a major contributor to the workload of emergency departments with a high volume of paediatric patients. As bronchiolitis is the leading cause of paediatric hospital admission, the same applies to paediatric inpatient services. In addition to calendar variables, innovative models of workforce and hospital activity planning could take into account the increased workload caused by the annual bronchiolitis epidemic if it was predictable.

\section{Limitations}

This study has several limitations. Recruitment for the study was not conducted all year and infants seen between the end of one bronchiolitis season and the beginning of the next season were excluded. Recruitment was started in April each year which included the peak presentation times for the previous 20 years in the sites involved. Recruitment was stopped two weeks after site investigators noted a marked decrease in presentations. It is entirely possible that admissions which occurred during the periods of nonrecruitment would have had a significant impact on the findings of our study, had they been included in the analysis and it is not possible to account for this. Anecdotally, sporadic cases of bronchiolitis occur offseason but the periods examined herewith likely represent a good approximation of the actual season.

Data were derived from a cohort with clinically defined bronchiolitis, whereas virological data were not available for all patients. Of the 2335 study subjects who were tested for respiratory viruses, 1089 (46.6\%) were positive for RSV. This suggests that extrapolation from our data to the subset of subjects with RSVrelated bronchiolitis is plausible. However, using only RSV as the measure of bronchiolitis ignores the many other viruses that cause the disease that may have different patterns of "activation". Using the clinical disease allows us to begin to understand the factors associated with increased workload due to bronchiolitis. In addition, our study examined subjects who were admitted to hospital. This cohort represents the sicker end of the spectrum of infants affected by bronchiolitis, but does not directly reflect the incidence of bronchiolitis in the community. 


\section{Conclusion}

We have identified a drop in temperature and increasing wind speeds as the weather events that are most consistently associated with increasing incidence of bronchiolitis. These events could potentially be used to predict workforce needs.

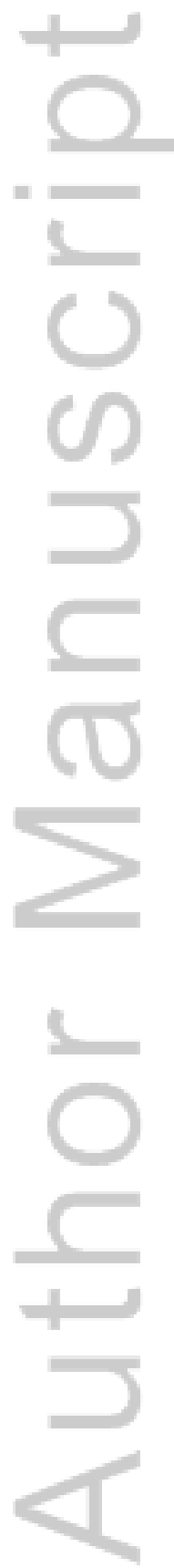

This article is protected by copyright. All rights reserved. 


\section{Acknowledgements}

We thank the participating families, the PREDICT research assistants and all participating clinicians. We declare no conflict of interest.

\section{References}

1. Clark SJ, Beresford MW, Subhedar NV, Shaw NJ. Respiratory syncytial virus infection in high risk =infants and the potential impact of prophylaxis in a United Kingdom cohort. Arch Dis Child. 2000;83(4):313-316.

2. Weigl JA, Puppe W, Schmitt HJ. Incidence of respiratory syncytial virus-positive hospitalizations in Germany. Eur J Clin Microbiol Infect Dis. 2001;20(7):452-459.

3. Resch B, Gusenleitner W, Mandl C, Muller W. Epidemiology of respiratory syncytial virus infection in Southern Austria. The Pediatric infectious disease journal. 2000;19(6):587-588.

4. Shay DK, Holman RC, Newman RD, Liu LL, Stout JW, Anderson LJ. Bronchiolitis-associated hospitalizations among US children, 1980-1996. JAMA. 1999;282(15):1440-1446.

5. Lister S, Mclntyre $P$, Menzies R. The epidemiology of respiratory syncytial virus infections in New South Wales children, 1992-1997. NSW Public Health Bull. 2000;11(7):119-123.

6. Moore H, Burgner D, Carville K, Jacoby P, Richmond P, Lehmann D. Diverging trends for lower respiratory infections in non-Aboriginal and Aboriginal children. J Paediatr Child Health. 2007;43(6):451-457.

7. Vogel A, Lennon D, Harding J. Trends in bronchiolitis admissions in New Zealand. Proceedings of the Paediatric Society of New Zealand. 2000;PO2.

8. Craig E, Anderson P, Jackson C. The Health Status of Children and Young People in Auckland DHB. The Health Status of Children and Young People in Auckland DHB2008.

9. Creery D, Lyer P, Samson L, Coyle D, Osborne G, MacDonald A. Costs associated with infant bronchiolitis in the Baffin region of Nunavut. Int J Circumpolar Health. 2005;64(1):38-45.

10. Smyth RL, Openshaw PJM. Bronchiolitis. Lancet. 2006;368(9532):312-322.

11. D'Souza RM, Bambrick HJ, Kjellstrom TE, Kelsall LM, Guest CS, Hanigan I. Seasonal variation in acute hospital admissions and emergency room presentations among children in the Australian Capital Territory. J Paediatr Child Health. 2007;43(5):359-365.

12. Zlateva KT, Vijgen L, Dekeersmaeker N, Naranjo C, Van Ranst M. Subgroup prevalence and genotype circulation patterns of human respiratory syncytial virus in Belgium during ten successive epidemic seasons. J Clin Microbiol. 2007;45(9):3022-3030.

13. Centers for Disease Control and Prevention (CDC). Respiratory syncytial virus activity - United States, July 2008-December 2009. Morbidity and mortality weekly report. 2010;59(8):230-233.

14. Centers for Disease Control and Prevention (CDC). Respiratory syncytial virus-United States, July 2007-June 2011. MMWR Morb Mortal Wkly Rep. 2011;60(35):1203-1206.

15. Mullins JA, Lamonte AC, Bresee JS, Anderson LJ. Substantial variability in community respiratory syncytial virus season timing. Pediatr Infect Dis J. 2003;22(10):857-862. 
16. Stensballe LG, Devasundaram JK, Simoes EA. Respiratory syncytial virus epidemics: the ups and downs of a seasonal virus. Pediatr Infect Dis J. 2003;22(2 Suppl):S21--S32.

17. De Silva LM, Hanlon MG. Respiratory syncytial virus: a report of a 5-year study at a children's hospital. J Med Virol. 1986;19(4):299-305.

18. Hierholzer JC, Tannock GA, Hierholzer CM, Coombs RA, Kennett ML, Phillips PA, et al. Subgrouping of respiratory syncytial virus strains from Australia and Papua New Guinea by biological and antigenic characteristics. Arch Virol. 1994;136(1-2):133-147.

19. Whitehall JS, Bolisetty S, Whitehall JP, Francis F, Norton R, Patole SK. High rate of indigenous bronchiolitis and palivuzumab. J Paediatr Child Health. 2001;37(4):416-417.

20. Surveillance EPH. New Zealand Virology Annual Report. New Zealand Virology Annual Report2011.

21. Dede A, Isaacs D, Torzillo PJ, Wakerman J, Roseby R, Fahy R, et al. Respiratory syncytial virus infections in children in Alice Springs Hospital. Medical Journal of Australia. 2008;188(4):261.

22. Moore HC, Keil AD, Richmond PC, Lehmann D. Timing of bronchiolitis hospitalisations and respiratory syncytial virus immunoprophylaxis in non-metropolitan Western Australia. Med J Aust. 2009;191(10):574.

23. Oakley E, Borland M, Neutze J, Acworth J, Krieser D, Dalziel S, et al. Nasogastric hydration versus intravenous hydration for infants with bronchiolitis: a randomised trial. Lancet Respir Med. 2013;1(2):113-120.

24. American Academy of Pediatrics Subcommittee on Diagnosis and Management of Bronchiolitis. Diagnosis and management of bronchiolitis. Pediatrics. 2006;118(4):1774-1793.

25. Hortal M, Meny M, Russi JC, Chiparelli $\mathrm{H}$. Meteorological variables and occurrence of respiratory syncytial virus in Uruguay. Research in virology. 1993;144(5):405-408.

26. Uduman SA, ljaz MK, Kochiyil J, Mathew T, Hossam MK. Respiratory syncytial virus infection among hospitalized young children with acute lower respiratory illnesses in Al Ain, UAE. The Journal of communicable diseases. 1996;28(4):245-252.

27. Reyes M, Hedlund KO, Lorenzana I, Ehrnst A. Respiratory infection and iatrogenic diarrhea in Honduras and El Salvador during the 1991-1992 season. The American journal of tropical medicine and hygiene. 1996;54(3):260-264.

28. Chew FT, Doraisingham S, Ling AE, Kumarasinghe G, Lee BW. Seasonal trends of viral respiratory tract infections in the tropics. Epidemiology and infection. 1998;121(1):121-128.

29. Straliotto SM, Nestor SM, Siqueira MM. Respiratory syncytial virus groups A and B in Porto Alegre, Brazil, from 1990 to 1995 and 1998. Memorias do Instituto Oswaldo Cruz. 2001;96(2):155-158.

30. Chan PW, Chew FT, Tan TN, Chua KB, Hooi PS. Seasonal variation in respiratory syncytial virus chest infection in the tropics. Pediatric pulmonology. 2002;34(1):47-51.

31. Lapeña S, Robles MB, Castañón L, Martínez JP, Reguero S, Alonso MP, et al. Climatic factors and lower respiratory tract infection due to respiratory syncytial virus in hospitalised infants in northern Spain. Eur J Epidemiol. 2005;20(3):271-276.

32. De Silva LM, Hanlon MG. Respiratory syncytial virus: a report of a 5-year study at a children's hospital. Journal of medical virology. 1986;19(4):299-305.

33. Ségala $C$, Poizeau $D$, Mesbah $M$, Willems $S$, Maidenberg $M$. Winter air pollution and infant bronchiolitis in Paris. Environ Res. 2008;106(1):96-100. 
34. Meerhoff TJ, Paget JW, Kimpen JL, Schellevis Fc. Variation of respiratory syncytial virus and the relation with meteorological factors in different winter seasons. Pediatr Infect Dis J. 2009;28(10):860-866.

35. du Prel J-B, Puppe W, Gröndahl B, Knuf M, Weigl JAI, Schaaff F, et al. Are meteorological parameters associated with acute respiratory tract infections? Clin Infect Dis. 2009;49(6):861-868.

36. Walton NA, Poynton MR, Gesteland PH, Maloney C, Staes C, Facelli JC. Predicting the start week of respiratory syncytial virus outbreaks using real time weather variables. BMC medical informatics and decision making. 2010;10:68.

37. Wang VJ, Cavagnaro CS, Clark S, Camargo CA, Jr., Mansbach JM. Altitude and environmental climate effects on bronchiolitis severity among children presenting to the emergency department. Journal of environmental health. 2012;75(3):8-15; quiz 54.

38. Chan PK, Sung RY, Fung KS, Hui M, Chik KW, Adeyemi-Doro FA, et al. Epidemiology of respiratory syncytial virus infection among paediatric patients in Hong Kong: seasonality and disease impact. Epidemiology and infection. 1999;123(2):257-262.

39. Reyes $M$, Eriksson $M$, Bennet $R$, Hedlund K-O, Ehrnst A. Regular pattern of respiratory syncytial virus and rotavirus infections and relation to weather in Stockholm, 1984-1993. Clin Microbiol Infect. 1997;3(6):640-646.

40. Hall CB, Douglas RG, Jr., Geiman JM. Possible transmission by fomites of respiratory syncytial virus. The Journal of infectious diseases. 1980;141(1):98-102.

41. Hambling MH. Survival of the Respiratory Syncytial Virus during Storage under Various Conditions. British journal of experimental pathology. 1964;45:647-655.

42. Hobson L, Everard ML. Persistent of respiratory syncytial virus in human dendritic cells and influence of nitric oxide. Clin Exp Immunol. 2008;151(2):359-366.

43. Pino $P$, Walter $T$, Oyarzun $M$, Villegas $R$, Romieu I. Fine particulate matter and wheezing illnesses in the first year of life. Epidemiology. 2004;15(6):702-708.

44. Karr C, Lumley T, Shepherd K, Davis R, Larson T, Ritz B, et al. A case-crossover study of wintertime ambient air pollution and infant bronchiolitis. Environ Health Perspect. 2006;114(2):277-281.

45. Falsey AR, Formica MA, Hennessey PA, Criddle MM, Sullender WM, Walsh EE. Detection of respiratory syncytial virus in adults with chronic obstructive pulmonary disease. American journal of respiratory and critical care medicine. 2006;173(6):639-643.

46. Morikawa S, Hiroi S, Kase T. Detection of respiratory viruses in gargle specimens of healthy children. Journal of clinical virology : the official publication of the Pan American Society for Clinical Virology. 2015;64:59-63.

47. Collins PL, Graham BS. Viral and host factors in human respiratory syncytial virus pathogenesis. Journal of virology. 2008;82(5):2040-2055.

48. Foxman EF, Storer JA, Fitzgerald ME, Wasik BR, Hou L, Zhao H, et al. Temperature-dependent innate defense against the common cold virus limits viral replication at warm temperature in mouse airway cells. Proceedings of the National Academy of Sciences of the United States of America. 2015;112(3):827-832.

49. Chase VJ, Cohn AEM, Peterson TA, Lavieri MS. Predicting emergency department volume using forecasting methods to create a "surge response" for noncrisis events. Acad Emerg Med. 2012;19(5):569-576. 
50. Jones SS, Thomas A, Evans RS, Welch SJ, Haug PJ, Snow GL. Forecasting daily patient volumes in the emergency department. Acad Emerg Med. 2008;15(2):159-170.

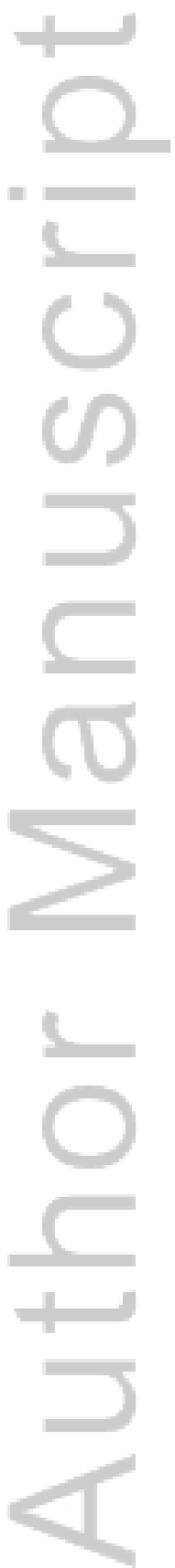

This article is protected by copyright. All rights reserved. 
Table 1: Linear regression analysis of weather variables and bronchiolitis admissions. Non-standardised correlation coefficients (B), 95\% confidence intervals (95\% Cl), standardised correlation coefficients (Beta) and $p$-values over different lag times.

\section{Minimum temperature}

\section{Wind speed}

\begin{tabular}{|c|c|c|c|c|c|c|c|c|}
\hline Lag & B & $95 \% \mathrm{Cl}$ & Beta & p-value & B & $95 \% \mathrm{Cl}$ & Beta & $p$-value \\
\hline 0 weeks & -0.62 & $-0.75,-0.48$ & -0.37 & $<0.001$ & 0.23 & $0.10,0.36$ & 0.23 & $<0.001$ \\
\hline 1 week & -0.58 & $-0.72,-0.43$ & -0.33 & $<0.001$ & 0.36 & $0.23,0.48$ & 0.36 & $<0.001$ \\
\hline 2 weeks & -0.67 & $-0.75,-0.58$ & -0.54 & $<0.001$ & 0.17 & $0.08,0.27$ & 0.18 & $<0.001$ \\
\hline 3 weeks & -0.34 & $-0.49,-0.20$ & -0.20 & $<0.001$ & 0.38 & $0.24,0.51$ & 0.39 & $<0.001$ \\
\hline 4 weeks & -0.24 & $-0.39,-0.09$ & -0.14 & $<0.001$ & 0.36 & $0.23,0.50$ & 0.37 & $<0.001$ \\
\hline
\end{tabular}

This article is protected by copyright. All rights reserved. 


\section{Figure legends}

Figure 1: Study site location and climate

Figure 2: Admissions per week (light grey line) and weekly average minimum temperature (dark grey line). Admissions are combined for cities with more than one site. Light grey and dark grey background shading indicate periods of partial and no recruitment, respectively. Melbourne: Royal Children's Hospital, Sunshine Hospital, Monash Medical Centre. Auckland: Starship Hospital, Kidz First Hospital

This article is protected by copyright. All rights reserved. 


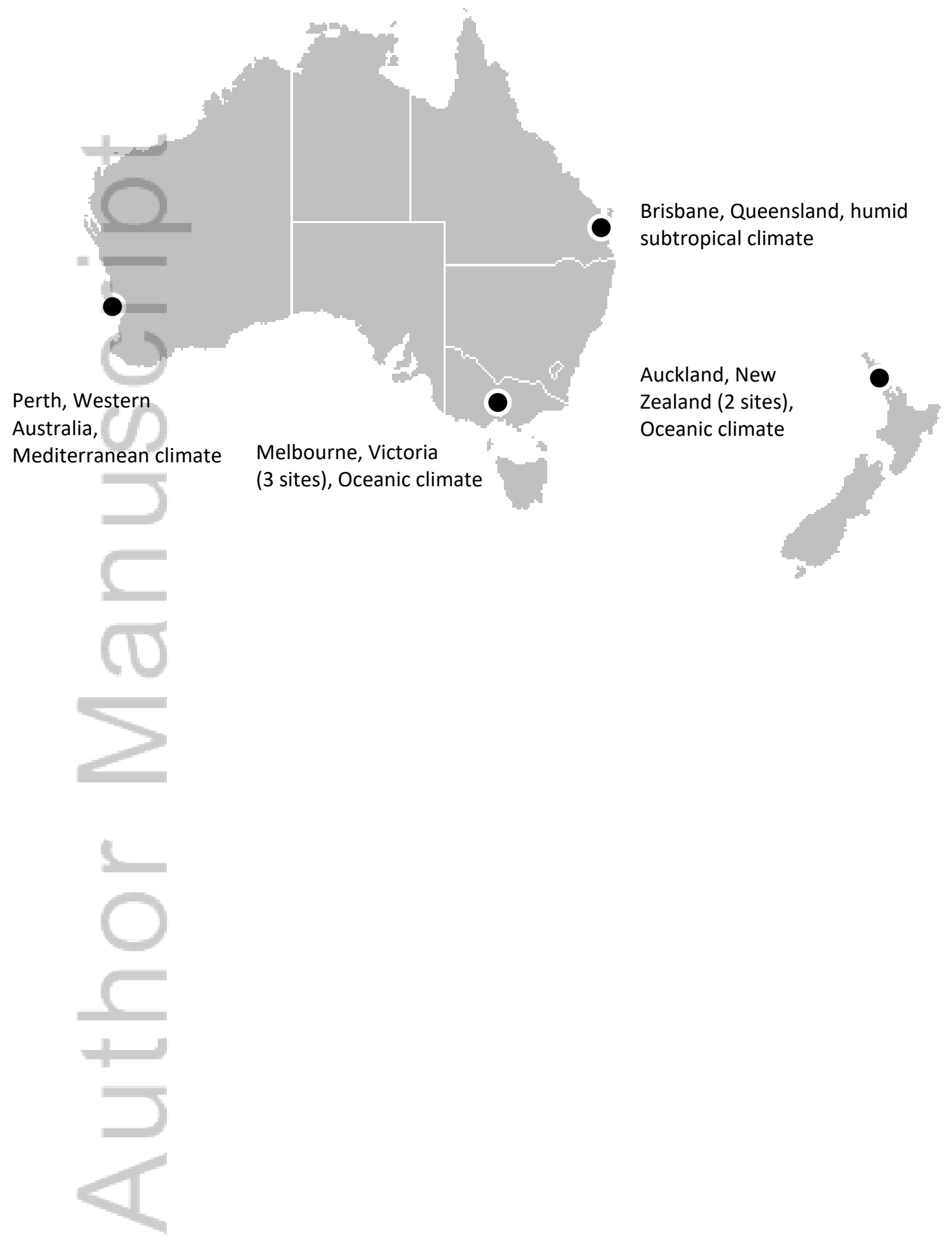

This article is protected by copyright. All rights reserved. 


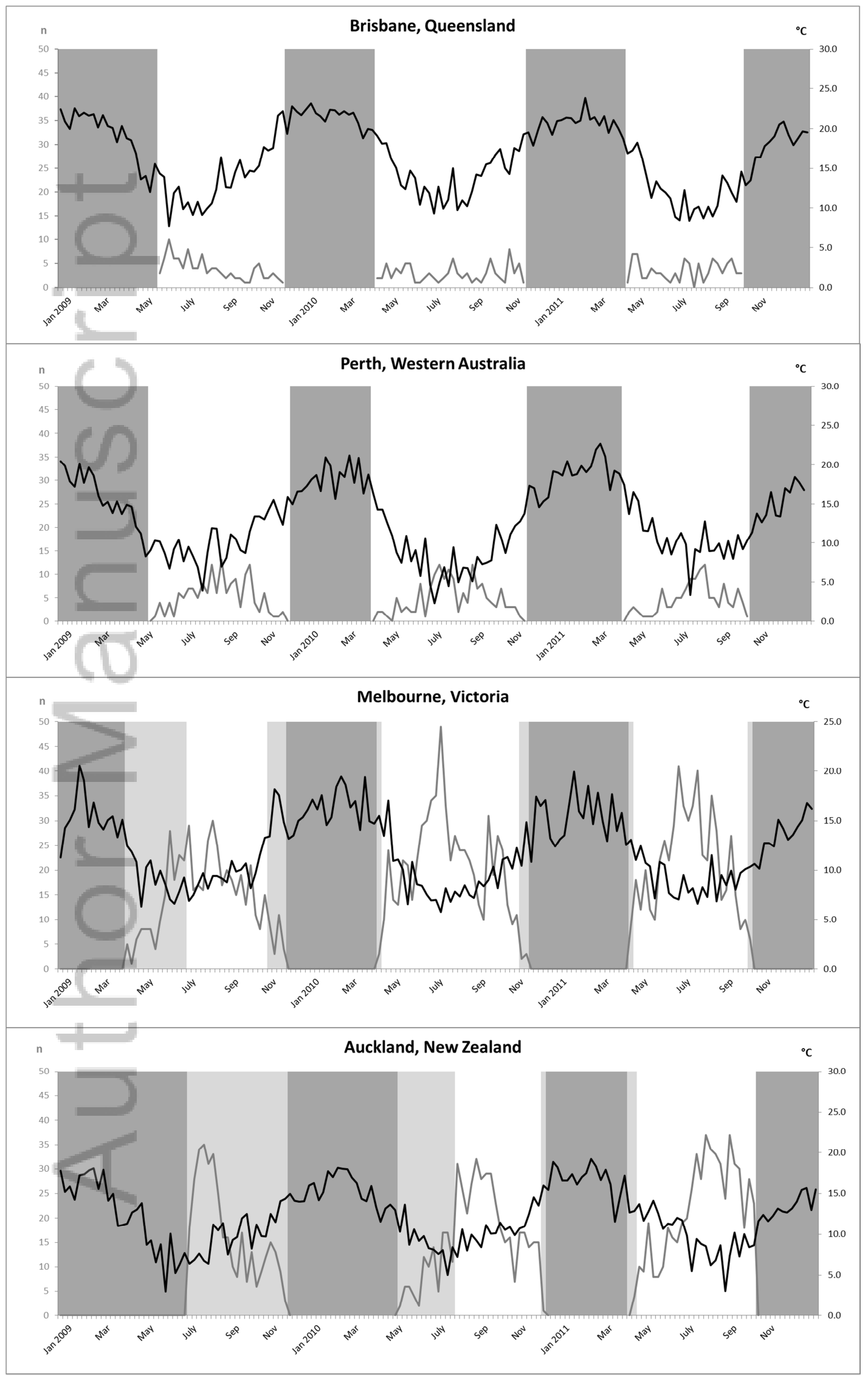

This article is protected by copyright. All rights reserved. 


\section{University Library}

\section{- M I N E R VA}

\section{A gateway to Melbourne's research publications}

Minerva Access is the Institutional Repository of The University of Melbourne

\section{Author/s:}

Hoeppner, T;Borland, M;Babl, FE;Neutze, J;Phillips, N;Krieser, D;Dalziel, SR;Davidson, A;Donath, S;Jachno, K;South, M;Williams, A;Zhang, G;Oakley, E

Title:

Influence of weather on incidence of bronchiolitis in Australia and New Zealand

Date:

2017-10-01

\section{Citation:}

Hoeppner, T., Borland, M., Babl, F. E., Neutze, J., Phillips, N., Krieser, D., Dalziel, S. R., Davidson, A., Donath, S., Jachno, K., South, M., Williams, A., Zhang, G. \& Oakley, E. (2017). Influence of weather on incidence of bronchiolitis in Australia and New Zealand. JOURNAL OF PAEDIATRICS AND CHILD HEALTH, 53 (10), pp.1000-1006. https://doi.org/10.1111/ jpc. 13614.

Persistent Link:

http://hdl.handle.net/11343/293200 